Identification of Groundwater Nitrate Contamination from Explosives used in Road Construction: Isotopic, Chemical, and Hydrologic Evidence

By James R. Degnan, J.K. Böhlke, Krystle Pelham, David M. Langlais, and Gregory J. Walsh

Supporting Information

15 pages

5 figures

5 tables (separate files) 


\section{Sampling and Analysis}

Filtered $(0.45 \mu \mathrm{m})$ groundwater samples for chemical and isotopic analyses were collected using cleaned chemically inert flexible tubing attached to existing plumbing ${ }^{1}$. Nitrate isotope samples were collected using a $0.2 \mu \mathrm{m}$ hydrophilic-polyethersulfone filter and were preserved with $\mathrm{KOH}$. Ammonium isotope samples were preserved with $\mathrm{H}_{2} \mathrm{SO}_{4}$. Dissolved gas samples (preserved with $\mathrm{KOH}$ ) were collected in serum bottles, which were filled through nylon tubing and sealed while submerged in a water-filled sample chamber ${ }^{2,3}$. Dissolved gas concentrations were measured by the USGS Reston Groundwater Dating Laboratory by gas chromatography on low-pressure headspace created in the serum bottles by removing water in the laboratory. Samples of blasted rock and samples of hydroseeding fertilizer also were collected. Soluble constituents were extracted from aliquots of blasted rock for chemical and isotopic analysis using either deionized water (DIW) or 3 molar potassium chloride $(\mathrm{KCl})$ solutions for analysis of $\mathrm{NO}_{3}{ }^{-}$ or $\mathrm{NH}_{4}{ }^{+}$, respectively. Perchlorate was analyzed at Texas Tech University by previously described methods ${ }^{4}$.

\section{Quality Control}

Replicate and equipment blank (from $\mathrm{NO}_{3}{ }^{-}$free water) samples were collected throughout the investigation (every 10 and 50 samples, respectively). Replicate samples had results below the LRL for $\mathrm{NO}_{3}{ }^{-}$in 2 of the 8 samples; the relative difference for the 8 replicates ranged from 0 to $6.3 \%$ with a mean of $1.4 \%$. Neither of two equipment blanks had measurable $\mathrm{NO}_{3}{ }^{-}$.

\section{Stable Isotopic Analyses}

Stable isotope ratios were measured by the USGS Reston Stable Isotope Laboratory ${ }^{3} \cdot \mathrm{H}_{2} \mathrm{O}$ was analyzed by isotope-ratio mass spectrometry (IRMS) of $\mathrm{H}$ and $\mathrm{O}$, respectively; data were normalized to the Vienna Standard Mean Ocean Water-Standard Light Antarctic Precipitation (VSMOW-SLAP) scale ${ }^{5}$, with typical 2-sigma (2-s) uncertainties of $\pm 1 \%$ and $\pm 0.1 \%$ for $\delta^{2} \mathrm{H}$ and $\delta^{18} \mathrm{O}$, respectively. Nitrate was reduced bacterially to $\mathrm{N}_{2} \mathrm{O}$ for IRMS of $\mathrm{N}$ and $\mathrm{O}^{6-8}$; data were normalized to reported reference values ${ }^{9}$ with typical 2 -s uncertainties of $\pm 0.5 \%$ and 1.0 $\%$, respectively. $\mathrm{NO}_{2}{ }^{-}$concentrations were negligible and were considered to have no significant effect on $\delta^{18} \mathrm{O}$ measurements of $\mathrm{NO}_{3}{ }^{-}$(Casciotti et al., 2007). $\mathrm{NH}_{4}{ }^{+}$was neutralized to $\mathrm{NH}_{3}$, concentrated by diffusion, and reacted with $\mathrm{O}_{2}$ to produce $\mathrm{N}_{2}$ for IRMS ${ }^{10}$; data were normalized to reported reference values ${ }^{11}$ with typical 2-s uncertainties of $\pm 0.8 \%$. Dissolved $\mathrm{N}_{2}$ in serumbottle headspace was pressurized, released to a constant-volume loop, separated from other gases in a mole-sieve gas chromatograph, and analyzed by continuous-flow IRMS; data were calibrated against air and air-saturated water samples with typical 2-s uncertainties of $\pm 0.2 \%$. Solid samples of blasted rock and fertilizer were ground, sieved, and homogenized, then reacted with $\mathrm{Cu}+\mathrm{CuO}$ to produce $\mathrm{N}_{2}$ for IRMS; data were normalized to reported reference values ${ }^{12}$ with typical 2-s uncertainties of $\pm 0.5 \%$; larger variations for some solid samples were attributed to sample heterogeneity.

\section{Reconstruction of "Initial recharge" Nitrate Concentrations and Isotope Ratios}

For each denitrified groundwater sample, the concentrations and $\delta^{15} \mathrm{~N}$ values of $\mathrm{NO}_{3}{ }^{-\circ}$ (initial $\mathrm{NO}_{3}{ }^{-}$, in recharge, prior to denitrification in the saturated zone) were reconstructed by combining 
the measured concentration and $\delta^{15} \mathrm{~N}$ value of $\mathrm{NO}_{3}{ }^{-}$with estimated concentration and $\delta^{15} \mathrm{~N}$ value of excess $\mathrm{N}_{2}$ attributed to denitrification in the sample ${ }^{13-15}$. The initial recharge $\delta^{18} \mathrm{O}$ value of $\mathrm{NO}_{3}^{-}$was then reconstructed by using a locally derived isotope fractionation ratio $\left(\Delta \delta^{15} \mathrm{~N} / \Delta \delta^{18} \mathrm{O}\right)$

Recharge temperature and excess air concentrations indicated by $\mathrm{Ar}$ and $\mathrm{N}_{2}$ concentrations in samples with $\mathrm{O}_{2}>1 \mathrm{mg} / \mathrm{L}$ (termed "oxic" and considered relatively unlikely to be denitrified) were used to calculate excess $\mathrm{N}_{2}$ concentrations in anoxic samples that were more likely denitrified. The precision of these calculations was limited in part by apparent variation in recharge temperature and excess air entrainment. Oxic samples had apparent recharge temperatures ranging from about 4 to $15^{\circ} \mathrm{C}$ and apparent excess (unfractionated) air concentrations of the order of 1-4 ccSTP/L, with some indication that higher excess air values corresponded generally to lower recharge temperatures (Figure S2a). Because varying recharge temperature appeared to be the major source of varying gas concentrations, and was not unexpected in this fractured-rock setting, excess $\mathrm{N}_{2}$ concentrations were estimated by assuming a common excess air concentration of $2.5 \mathrm{ccSTP} / \mathrm{L}$ (near the midpoint of the oxic groundwater results) and allowing temperature to vary accordingly. Using 1 and $4 \mathrm{ccSTP} / \mathrm{L}$ as limiting excess air assumptions, overall estimated uncertainties of calculated excess $\mathrm{N}_{2}-\mathrm{N}$ concentrations were of the order of $\pm 1.2 \mathrm{mg} / \mathrm{L}$. This is two times the standard deviation of the calculated excess $\mathrm{N}_{2}$ concentrations of the oxic samples $(0.4 \pm 0.6 \mathrm{mg} / \mathrm{L}(\mathrm{n}=12)$.

The $\delta^{15} \mathrm{~N}$ value of excess $\mathrm{N}_{2}$ in each sample was calculated by assuming the sample contained a mixture of (1) dissolved gases from recharge with $\mathrm{N}_{2}$ from recharge with $\mathrm{Ar} / \mathrm{N}_{2}=0.0351$ $\mathrm{mg} / \mathrm{mg}$ and $\delta^{15} \mathrm{~N}=0.7 \%$ (mean values for oxic samples) and (2) excess $\mathrm{N}_{2}$ with $\mathrm{Ar} / \mathrm{N}_{2}=0$ (by linear extrapolation in Figure S2b). The value of $\Delta \delta^{15} \mathrm{~N} / \Delta \delta^{18} \mathrm{O}$ used in this study (1.31) was derived from the array of $\delta^{15} \mathrm{~N}$ and $\delta^{18} \mathrm{O}$ data representing variably reduced $\mathrm{NO}_{3}{ }^{-}$in residential area wells (Figure 1A). This value is consistent with laboratory studies that indicate the relative rates of change of $\delta^{15} \mathrm{~N}$ and $\delta^{18} \mathrm{O}$ during $\mathrm{NO}_{3}{ }^{-}$reduction (including denitrification) are approximately equal, and with field studies indicating apparent $\Delta \delta^{15} \mathrm{~N} / \Delta \delta^{18} \mathrm{O}$ ratios between 1 and 2 in reducing groundwater (see text).

Uncertainties in initial ("recharge") values of NO3- concentration and isotopic compositions can be especially large for samples with low concentrations of NO3- and excess N2; for example, samples from W1064 with relatively low estimated $\delta 15 \mathrm{~N}$ values (negative in one case) may not be as anomalous as they appear. Such calculations could be improved by additional analyses of $\mathrm{Ne} \pm$ other noble gases for better resolution of recharge temperature and excess air concentrations $^{16-17}$. 


\section{Informal Narrative Interpretations of Sources and Sample Sites}

\section{Blasting Compounds}

Components of blasting compounds used at this construction site are summarized in Table S4. Trinitrotoluene (TNT) and Dinitrotoluene (DNT) (found in some blasting compounds) can take decades to attenuate and can produce $\mathrm{NO}_{3}{ }^{-}$. Some reports have suggested degradation of $\mathrm{N}-$ based explosives and propellants could be a source of $\mathrm{NO}_{3}{ }^{-}$contamination in groundwater, with isotopic characteristics that may be distinguishable from other $\mathrm{NO}_{3}{ }^{-}$sources ${ }^{18-20}$, but supporting data from the field are scarce. Limited experiments indicate $\mathrm{NO}_{3}{ }^{-}$produced during photochemical cyclotrimethylenetrinitramine (RDX) degradation can have relatively low $\delta^{15} \mathrm{~N}$ values compared to other major $\mathrm{NO}_{3}{ }^{-}$sources, whereas $\delta^{18} \mathrm{O}$ results appear to be more variable ${ }^{18 \text {, }}$ 19. Groundwater $\mathrm{NO}_{3}{ }^{-}$in some areas of $\mathrm{RDX}$ contamination did not exhibit those characteristics, possibly because other $\mathrm{NO}_{3}{ }^{-}$sources were more important ${ }^{18}$.

Approximately 20,000 to $26,000 \mathrm{~kg}$ of $\mathrm{N}$ of which 10,000 to $13,000 \mathrm{~kg}$ was $\mathrm{N}$ of $\mathrm{NO}_{3}{ }^{-}$was used in blasting upgradient of each well (Table S5) adjacent to 2013-2014 blasting, which is enough to contaminate between approximately $1 \times 10^{6}$ to $8 \times 10^{7} \mathrm{~L}$ of water over the MCL $(10 \mathrm{mg} / \mathrm{L})$ assuming a residual of 0.1 to $6 \%^{21,22}$. Nitrogen in blasting compounds used upgradient of wells were summarized by well if they intersected a hypothetical potential contributing recharge area (buffer) extending $100 \mathrm{~m}$ on both sides of a flow vector upgradient from the wells.

Perchlorate was not found in any of the blasting compounds used on site, but it is listed as an ingredient on the Material Safety Data Sheet (MSDS) for certain blasting delay devices, along with aluminum. Masses and components of blasting delay devices were not quantified for this study, but are recorded in the blasting reports for this construction site.

Blasted rock Two samples of residual coatings of blasting compounds on chips of basted rock were prepared for chemical and isotopic analysis using deionized water and $\mathrm{KCl}$ solution leaches. Two 3-gallon buckets of rock chips (each with a different source rock color) were collected on 4/15/2014 from a site where blasting occurred on 4/11/2014. The samples were sieved through a $7.9 \mathrm{~mm}$ screen, homogenized separately from each bucket, separated into two (roughly $250 \mathrm{~mL}$ ) equal sized smaller bags per bucket and were frozen and shipped to the Reston Stable Isotope Lab (RSIL). Samples were split into $500 \mathrm{~mL}$ wide-mouthed Nalgene bottles at the RSIL and agitated for 2-3 hours. Water from the leachate was prefiltered ( 0.45 micron), then filtered again at 0.2 microns. Twenty $\mathrm{mL}$ of each sample was submitted for chemical analysis. Two hundred $\mathrm{mL}$ of each sample was removed and preserved with $\mathrm{H}_{2} \mathrm{SO}_{4}$. The remainder of the sample $(\sim 80 \mathrm{~mL})$ was measured and preserved with $\mathrm{KOH}$. Rock chip leachates had $\mathrm{NO}_{3}{ }^{-}$with low $\delta^{15} \mathrm{~N}$ and high $\delta^{18} \mathrm{O}$. Rock chip leachates had relatively low $\mathrm{NH}_{4}^{+}$concentrations $(0.5 \mathrm{mg}-$ $\mathrm{N} / \mathrm{L}$ in sample 1 DIW leachate; less in sample 2 DIW leachate).

Fertilizer There was a total of $235 \mathrm{~kg}$ of $\mathrm{N}$ applied in the form of "hydroseed" fertilizer throughout the site during the project. Eighty-one percent of the total (190kg of N) hydroseed mixture used at the highway site was applied in July 2013. Nitrate was not listed on the MSDS sheets; urea was the main $\mathrm{N}$ component. Fertilizer application occurred at the same time as seeding. Samples of fertilizer used in hydroseed application were dissolved in deionized water for isotopic analysis. Observations of fertilizers and leachates are: 1) fertilizers did not have 
$\mathrm{NO}_{3}-\mathrm{N}$; 2) fertilizer 24-0-5 had bulk $\delta^{15} \mathrm{~N}$ near $-2 \%$; 3) fertilizer $19-19-19$ had bulk $\delta^{15} \mathrm{~N}$ around $+3 \%$. The mass weighed $\delta^{15} \mathrm{~N}$ for the fertilizer was -1.55 . The total mass of $\mathrm{N}$ applied as hydroseed fertilizer in the study area was of the order of $10^{-3}$ to $10^{-2}$ times the mass of $\mathrm{N}$ applied in explosives in 2013-2014.

S1 is a spring (figure S1) draining out of a pile of blasted rock where blasting occurred between March and September, 2013. Samples from spring S1 had a $\mathrm{NO}_{3}{ }^{-}$concentration of $48.3 \mathrm{mg}-\mathrm{N} / \mathrm{L}$ with high $\delta^{18} \mathrm{O}$ and low $\delta^{15} \mathrm{~N}$ during blasting in June of 2013 and a $\mathrm{NO}_{3}{ }^{-}$concentration $4.82 \mathrm{mg}-$ $\mathrm{N} / \mathrm{L}$ with lower $\delta 18 \mathrm{O}$ and low $\delta^{15} \mathrm{~N}$ in April, 2014 almost a year after blasting was finished in this area. Spring S1 had an initial boron concentration of $62 \mu \mathrm{g} / \mathrm{L}$, near the concentration of septic system influenced well W670, the second sample approximately a year later had a concentration of $10 \mu \mathrm{g} / \mathrm{L}$, near the concentration of spring S2 and monitoring well W1062. Boron could be associated with igneous rocks or septic systems, but there was not a septic source in this area. The location was identified as having developed open space land cover on the USGS National map, updated 2011. Ammonium in spring S1 had a $\delta^{15} \mathrm{~N}$ of $2.0 \%$ in June, 2013, which is consistent with synthetic $\mathrm{NH}_{4}{ }^{+}$. Ammonium was not detected in the April, 2014 sample.

S2 is a spring located upgradient from blasting and out of the influence of other sources of local anthropogenic groundwater contamination. Nitrate, $\mathrm{NH}_{4}{ }^{+}$and perchlorate are below detection limits. The spring had a boron concentration of $10 \mu \mathrm{g} / \mathrm{L}$. The setting had mixed forest land cover on the USGS National map, updated 2011. Non detects of $\mathrm{ClO}_{4}{ }^{-}$in the background sample S2 indicates $\mathrm{ClO}_{4}{ }^{-}$in samples from other wells may be largely from local anthropogenic sources. The "background" water from S2 for comparison with other samples had a $\mathrm{pH}$ of 6.5, specific conductance was $68.4 \mu \mathrm{S} / \mathrm{cm}, \mathrm{Ca} 6.29 \mathrm{mg} / \mathrm{L}, \mathrm{Mg} 0.81 \mathrm{mg} / \mathrm{L}, \mathrm{SO}_{4}{ }^{2-} 11.4 \mathrm{mg}-\mathrm{N} / \mathrm{L}$ and the highest orthophosphate in the study, $0.023 \mathrm{mg} / \mathrm{L}$.

W492 is a domestic water supply well located 155 meters downgradient of an area impacted by blasting that occurred between June 2013 and May 2014. The well location is identified as developed medium intensity land on the USGS National map, updated 2011. The lot size where the well is located is $0.31 \mathrm{ha}$, an adjacent lot covers 0.85 ha. This domestic well had $\mathrm{NO}_{3}{ }^{-}$ concentrations below the detection limit from February 2013 through June 2014. $\mathrm{NO}_{3}{ }^{-}$was detected in July 2014 and increased subsequently to $13.7 \mathrm{mg}-\mathrm{N} / \mathrm{L}$ in October. Denitrification, suggested by low $\mathrm{O}_{2}$ and reducing conditions, may have prevented some $\mathrm{NO}_{3}{ }^{-}$from reaching W492. This suggests a poor connection with the surface and older water. It took more than a year for $\mathrm{NO}_{3}{ }^{-}$to be detected and increase in well W492. W492 has a $0.379 \mathrm{~L} / \mathrm{s}$ yield.

W660 is a domestic water supply well located in a dense residential setting 500 meters downgradient of blasting and adjacent to Cobbetts Pond. The well location is on developed low intensity land as indicated on the USGS National map, updated 2011. The lot size where the well is located is $0.25 \mathrm{ha}$, the adjacent lot size is $0.03 \mathrm{ha}$. This domestic well had relatively low $\mathrm{NO}_{3}{ }^{-}$, high $\delta^{15} \mathrm{~N}$ and $\delta^{18} \mathrm{O}$, plus excess $\mathrm{N}_{2}$, consistent with partially denitrified septic system $\mathrm{NO}_{3}{ }^{-}$(i.e., W660 could be considered a partially denitrified equivalent of W670). Multiple samples indicate minor variations in $\mathrm{NO}_{3}{ }^{-}$concentration, $\delta^{15} \mathrm{~N}$, and $\delta^{18} \mathrm{O}$ that plot along a $\mathrm{NO}_{3}{ }^{-}$reduction trend. $\mathrm{NO}_{3}{ }^{-}$concentrations do not have evidence of blasting impacts.

W670 is a domestic water supply well located in a dense residential area, 320 meters downgradient of blasting and adjacent to Cobbetts Pond. The well is located in developed medium intensity land as indicated on the USGS National map, updated 2011. Lot size is 0.06 
ha, adjacent lot size is 0.06 ha. This well may be affected by biogenic $\mathrm{NO}_{3}{ }^{-}$and had moderately high $\mathrm{NO}_{3}{ }^{-}$and $\delta^{15} \mathrm{~N}$ with relatively low $\delta^{18} \mathrm{O}$ and no evidence of denitrification, so may represent septic system $\mathrm{NO}_{3}{ }^{-}$. Multiple samples were similar, and plot close together on a $\mathrm{NO}_{3}{ }^{-}$reduction line, relative stability and no evidence of blasting impact. Well W670 may indicate connection to shallow groundwater and has septic-sourced $\mathrm{NO}_{3}{ }^{-}$and a $0.505 \mathrm{~L} / \mathrm{s}$ yield.

W870 is a domestic water-supply well in a dense residential area, 360 meters downgradient of blasting and adjacent to Cobbetts Pond. The well location has a developed low intensity land cover on the USGS National map, updated 2011. The lot size is 0.04 ha, adjacent lot size is 0.04 ha. Multiple isotope samples indicate relative stability of isotope ratios. $\delta^{15} \mathrm{~N}$ and $\delta^{18} \mathrm{O}$ plot at the lower end of the values measured from W660 indicating a lack of fractionation from denitrification. $\mathrm{NO}_{3}{ }^{-}$concentrations dropped to near the detection limit between January and June 2014 (HTE, 2014) and likely represent a seasonal use pattern of septic system discharge. No evidence of blasting impact. This well has denitrifying conditions.

W1061 is a water-supply well for an 8600 square foot office building. The well location is characterized with developed low intensity land cover on the USGS National map, updated 2011. The well is on a 0.77 ha lot, the adjacent lot size is 1.62 ha. The well is 92 meters downgradient of the centerline of blasting that occurred between May 2013 and January 2014. The initial $\mathrm{NO}_{3}{ }^{-}$ concentration was $0.13 \mathrm{mg}-\mathrm{N} / \mathrm{L}$ before blasting with low $\delta^{18} \mathrm{O}$ and $\delta^{15} \mathrm{~N}$, representing synthetic nitrified or soil N. It is not clear if the low $\mathrm{NO}_{3}{ }^{-}$concentration prior to blasting was due to soil, fertilizer or leaching of older blasting residue (similar to W1062). After blasting in May of 2013, the concentration of $\mathrm{NO}_{3}{ }^{-}$increased to $1.94 \mathrm{mg}-\mathrm{N} / \mathrm{L}$ with high $\delta^{18} \mathrm{O}$ and constant low $\delta^{15} \mathrm{~N}$, with no evidence of denitrification, consistent with arrival of explosive $\mathrm{NO}_{3}$ - pulse (explosive $\mathrm{NO}_{3}{ }^{-}$ dominates isotopes rapidly because background $\mathrm{NO}_{3}{ }^{-}$concentration is very low). The peak $\mathrm{NO}_{3}{ }^{-}$ concentration $(28.4 \mathrm{mg} / \mathrm{L})$ occurred (February 2014) one month after the blasting ended, followed by a sharp decline. A second peak in $\mathrm{NO}_{3}{ }^{-}(21.1 \mathrm{mg}-\mathrm{N} / \mathrm{L}$ in October 2014) began after the decline from the initial peak and has lower $\delta^{18} \mathrm{O} . \delta^{18} \mathrm{O}$ had a peak value in June of 2013 and has been decreasing. An adjacent road cut was used as blasted rock storage in September and October of 2014 and may have contributed to the second $\mathrm{NO}_{3}{ }^{-}$peak. $\mathrm{NO}_{3}{ }^{-}$increased in $\mathrm{W} 1061$ within a month of blasting, which had high $\mathrm{O}_{2}$ and variable sodium and chloride, suggesting that this well captured shallow groundwater flow from the blasting area. W1061 has a relatively high yield $(1.89 \mathrm{~L} / \mathrm{s})$ and moderate to shallow depth to water $(1.86 \mathrm{~m})$.

W1062 is a monitoring well in a $\mathrm{NO}_{3}{ }^{-}$-impacted groundwater-management zone adjacent to the site where blasting and rock debris from blasting was used to construct an exit ramp in 2009. The well is located in developed (medium intensity) land on the boarder of a deciduous forest as shown on the USGS National map, updated 2011. The highest $\mathrm{NO}_{3}{ }^{-}$concentration was $170 \mathrm{mg}-$ $\mathrm{N} / \mathrm{L}$ in February of 2010 (Continental Placer, 2010). Nitrate concentrations measured during this study varied slightly between 23.8 and 14.7 and had a decreasing trend. $\delta^{18} \mathrm{O}$ and $\delta^{15} \mathrm{~N}$ of $\mathrm{NO}_{3}{ }^{-}$ have been consistently low. The low $\delta^{15} \mathrm{~N}$ and $\delta^{18} \mathrm{O}$ isotope ratios from well W1062 are not a common synthetic $\mathrm{NO}_{3}{ }^{-}$signature, but it could be $\mathrm{NO}_{3}^{-}$formed locally from transformation of synthetic $\mathrm{NH}_{4}{ }^{+}$. There may have been two pulses of high $\mathrm{NO}_{3}{ }^{-}$groundwater that affected this well, an initial flush of unaltered synthetic $\mathrm{NO}_{3}{ }^{-}$likely occurred in 2009 after blasting, then a delayed pulse of $\mathrm{NO}_{3}{ }^{-}$from $\mathrm{NH}_{4}{ }^{+}$oxidation that is observed in this study. $\delta^{15} \mathrm{~N}$ of $\mathrm{NH}_{4}{ }^{+}$varied between 4 and $11 \%$ and was much higher than isotope ratios from recent blasting. Ammonium can sorb to soil/rock easily and is desorbed slowly; $\mathrm{NH}_{4}{ }^{+}$is likely undergoing nitrification and 
contributing $\mathrm{NO}_{3}{ }^{-}$to well W1062. Ammonium oxidation could cause the $\delta^{15} \mathrm{~N}$ of the residual $\mathrm{NH}_{4}{ }^{+}$to increase. That could also be a source of $\mathrm{NO}_{3}{ }^{-}$with relatively low $\delta^{15} \mathrm{~N}$ and low $\delta^{18} \mathrm{O}$. Samples from W1062 with varying redox conditions and adjacent to the 2009 blasting did not have measurable excess $\mathrm{N}_{2}$, but did have slightly low $\delta^{15} \mathrm{~N}$ of $\mathrm{N}_{2}$ indicating incipient partial denitrification. W1062 has a very low yield $(0.0039 \mathrm{~L} / \mathrm{s})$, moderate depth to water $(1.04 \mathrm{~m})$ and variable $\mathrm{O}_{2}$. Nitrate occurrence began after 2009 blasting, peaked at $170 \mathrm{mg}-\mathrm{N} / \mathrm{L}$ in 2010 , and persists today at levels in the $20 \mathrm{mg}-\mathrm{N} / \mathrm{L}$ range, likely from nitrification of sorbed ammonium.

W1063 is a water supply well for the NHDOT field office located 60 meters downgradient of the centerline of blasting used for construction between September 2013 and May 2014. The well is located on a 0.33 ha lot (adjacent lot size is 1.62 ha) and is identified as having deciduous forest land cover on the USGS National map, updated 2011. Despite the close proximity to the blasting, water samples from the well didn't have any detections of $\mathrm{NO}_{3}{ }^{-}$until July 2014 . The $\delta^{15} \mathrm{~N}$ of $\mathrm{N}_{2}$ had a 0.7-3.1 \% initial value. The recharge temperature was right at the lower limit. Gas data from W1063 consistently indicated denitrification. Nitrate was detected in August and October 2014 samples. $\mathrm{SO}_{4}{ }^{2-}, \mathrm{Ca}$, and $\mathrm{Mg}$ rose slightly through the study, then the $\mathrm{SO}_{4}{ }^{2-}$ concentration doubled with the $\mathrm{NO}_{3}{ }^{-}$detections. $\mathrm{Cl}$ decreased with time. Groundwater in this well had a mixed $\mathrm{NO}_{3}{ }^{-}$source, modified by denitrification. Denitrification is supported by excess $\mathrm{N}_{2}$ gas data, low $\mathrm{O}_{2}$, and reducing conditions, which may have prevented some $\mathrm{NO}_{3}{ }^{-}$from reaching $\mathrm{W} 1063$. Low $\mathrm{O}_{2}$, and a relatively deep water surface condition $(6.97 \mathrm{~m})$ suggest possible lag in contaminant break through time after blasting. Low $\mathrm{O}_{2}$, high $\mathrm{pH}$ at W1063 suggests older water. It took more than a year for $\mathrm{NO}_{3}{ }^{-}$to be detected and increase in well W1063. W1063 does have a relatively high yield, $1.89 \mathrm{~L} / \mathrm{s}$.

W1064 is a public-water-supply well located 122 meters downgradient from an area blasted between June 2013 and May 2014. The well is located on a 0.81 ha lot (adjacent lot size is 0.74 ha) and is identified as having deciduous forest land cover on the USGS National map, updated 2011. W1064 had increasing $\mathrm{NO}_{3}{ }^{-}$concentrations starting in June 2013, concentrations peaked at $15.6 \mathrm{mg}-\mathrm{N} / \mathrm{L}$ in February then declined to 6.92 in April 2014. Concentrations rose again from April, 2014 to a new peak of $30 \mathrm{mg}-\mathrm{N} / \mathrm{L}$ in October 2014. $\delta^{18} \mathrm{O}$ of $\mathrm{NO}_{3}{ }^{-}$increased to around 20 \%o from July to November 2013 and has decreased slightly through June of 2014 . Low $\delta^{15} \mathrm{~N}$ values have decreased with initial increase in $\mathrm{NO}_{3}{ }^{-}$, then slightly increased. Nitrate was not detected in preblasting samples from W1064. W1064 had anoxic groundwater for the first time in August 2014. Nitrate is largely derived from blasting source.

W1065 is a domestic water-supply well located 175 meters downgradient from blasting that occurred between May 2013 and March 2014. The well is on a 0.45 ha lot (adjacent lot is 0.20 ha) and is identified as having developed medium intensity land cover on the USGS National map, updated 2011. Nitrate concentrations had an early peak of $1.33 \mathrm{mg}-\mathrm{N} / \mathrm{L}$ in December 2013, then decreased below the detection limit. A second increase started in May and has continued until October 2014 with a concentration of $2.99 \mathrm{mg}-\mathrm{N} / \mathrm{L}$ (HTE, 2014). $\delta^{18} \mathrm{O}$ and $\delta^{15} \mathrm{~N}$ values from this well suggest a denitrification trend. Nitrate concentrations from W1065 are near detection limit and although partially reduced, suggest a source that would indicate nitrified synthetic N.

W1066 is a domestic water supply well located on a 0.79 ha lot (adjacent to a 0.11 ha lot) 300 meters downgradient from blasted areas. The land is identified as having a developed low intensity land cover on the USGS National map, updated 2011. This well has not had detectable 
$\mathrm{NO}_{3}{ }^{-}$concentrations, gas analysis indicate initial/original $2.3 \mathrm{mg}-\mathrm{N} / \mathrm{L} \mathrm{NO}_{3}{ }^{-}$concentration and 5.4 ${ }_{0} \delta^{15} \mathrm{~N}$ value. Low $\mathrm{O}_{2}$ and high $\mathrm{pH}$ indicate chemically evolved groundwater with a denitrifying capacity.

W1067 is a community water-supply well located 218 meters downgradient from June 2013 to May 2014 blasting. The well is located on a 0.08 ha lot (adjacent lot size is 0.09 ha). The lot has developed medium intensity land cover identified on the USGS National map, updated 2011. Nitrate concentrations in this well were below $0.4 \mathrm{mg}-\mathrm{N} / \mathrm{L}$ before blasting, and in August of 2013 they began to increase to a maximum of $5.46 \mathrm{mg}-\mathrm{N} / \mathrm{L}$ (HTE, 2014) in March of 2014. Concentrations increased again from June through October 2014 with a maximum concentration of 5.78 and a similar time series pattern to W1061. Low $\delta^{15} \mathrm{~N}$ and high $\delta^{18} \mathrm{O}$ values from $\mathrm{NO}_{3}{ }^{-}$ concentrations in groundwater in this well plot in the range of synthetic $\mathrm{NO}_{3}{ }^{-}$from explosives.

W1069 is a water-supply well for an 824 square foot office building located 50 meters downgradient of an area blasted between June 2013 and May 2014. The well is located on a 0.36 ha lot (neighboring lot $0.81 \mathrm{ha}$ ) and is identified as having deciduous forest land cover on the USGS National map, updated 2011. Samples from this well had peak concentrations of 3.29 (HTE) and 5.57 in March and October, respectively. Low $\delta^{15} \mathrm{~N}$ and $\delta^{18} \mathrm{O}$ values from $\mathrm{NO}_{3}{ }^{-}$ concentrations fall within the range of biogenic $\mathrm{NO}_{3}{ }^{-}$from soil or synthetic nitrified N. $\delta^{18} \mathrm{O}$ values have decreased while $\delta^{15} \mathrm{~N}$ values have slightly increased indicating mixed sources. 


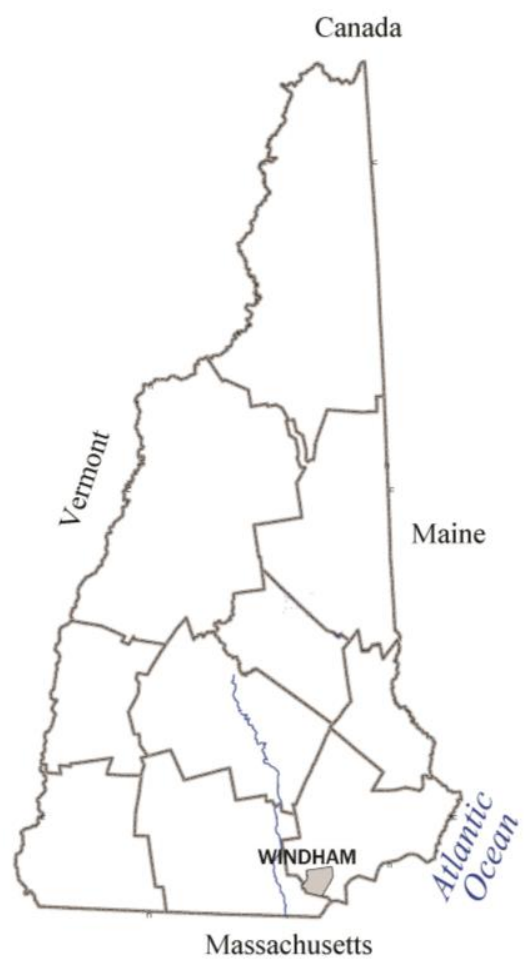

b
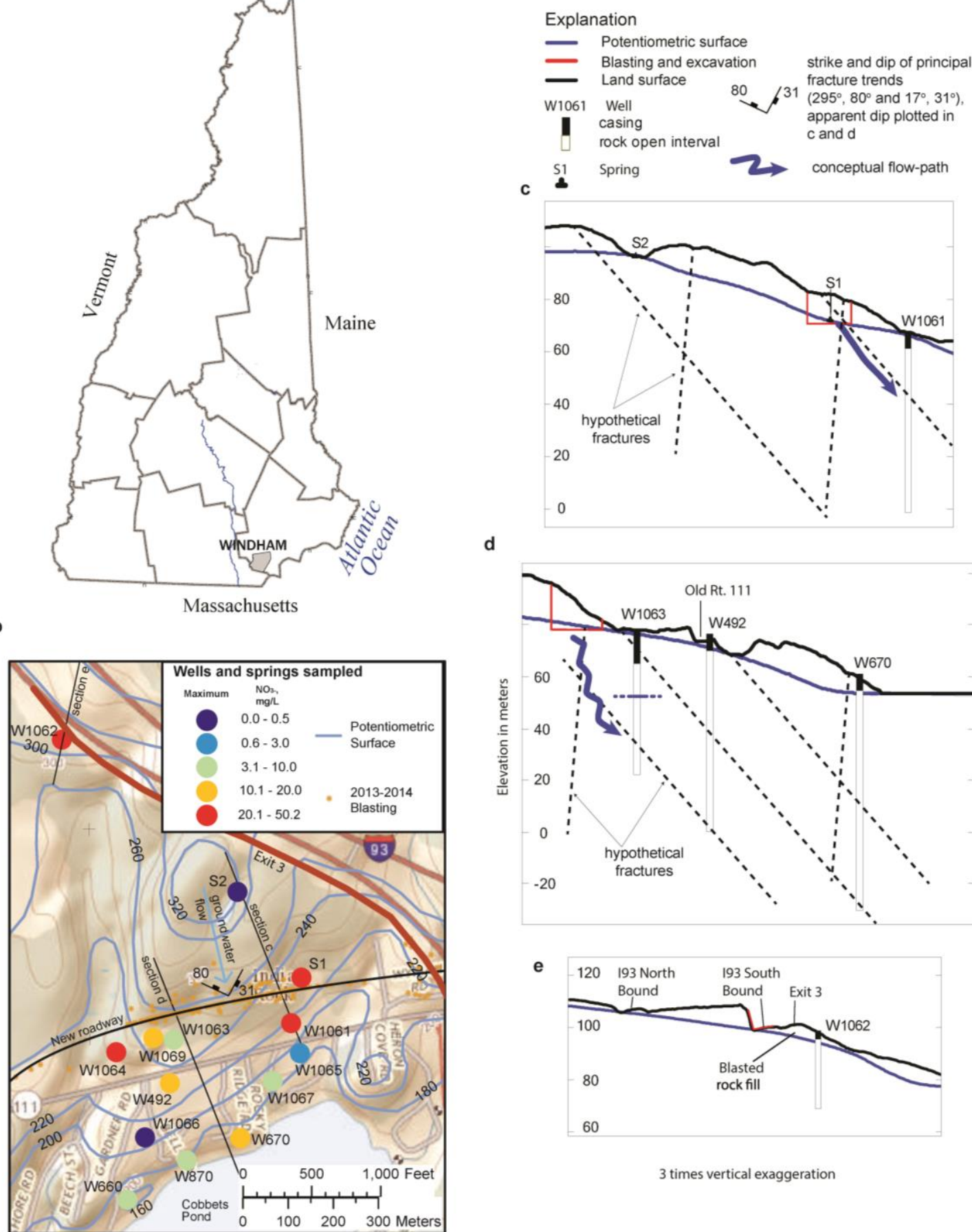

d

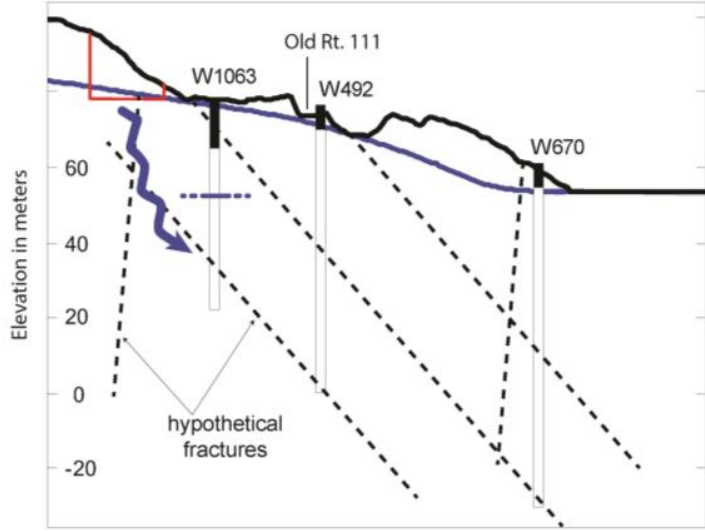

e

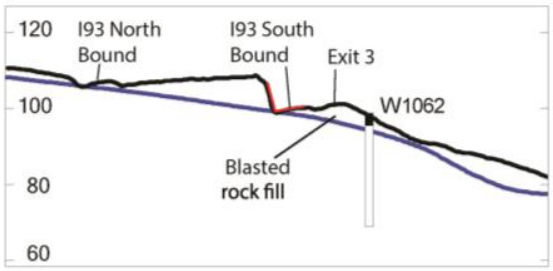

3 times vertical exaggeration

Figure S1. Site characterization maps and cross-sections, (A) Map of New Hampshire showing the location of the study area in Windham, New Hampshire; (B) Map of the study area showing the potentiometric surface, and locations of blasting sites, wells, and springs with pre blasting and maximum post-blasting $\mathrm{NO}_{3}{ }^{-}$concentrations; (C) Cross-section including spring S2, representing background conditions, spring S1with blasted conditions and well W1061, representing rapid $\mathrm{NO}_{3}{ }^{-}$concentration response to 2013 blasting; (D) Cross-section, including well W670 with persistent septic source and wells W1063 and W492 with denitrification and slow $\mathrm{NO}_{3}{ }^{-}$response to blasting; (E) Cross-section including well W1062 representing persistent response to 2009 blasting, $\mathrm{NH}_{4}{ }^{+}$source, and blasted rock fill. 
a

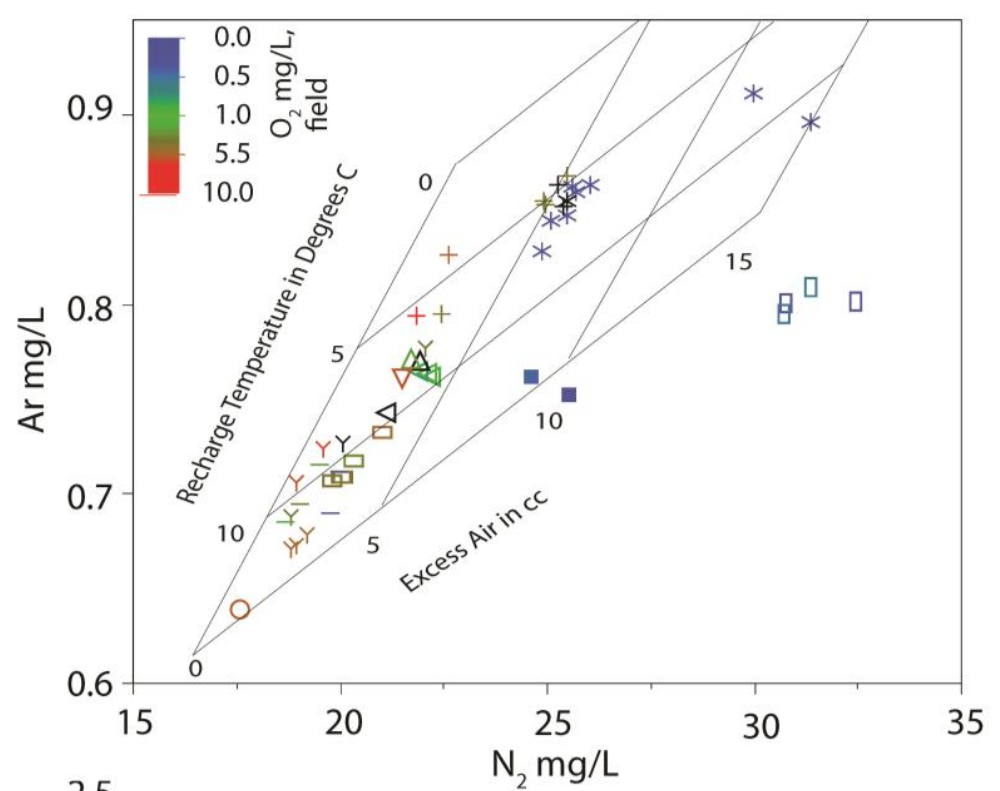

b

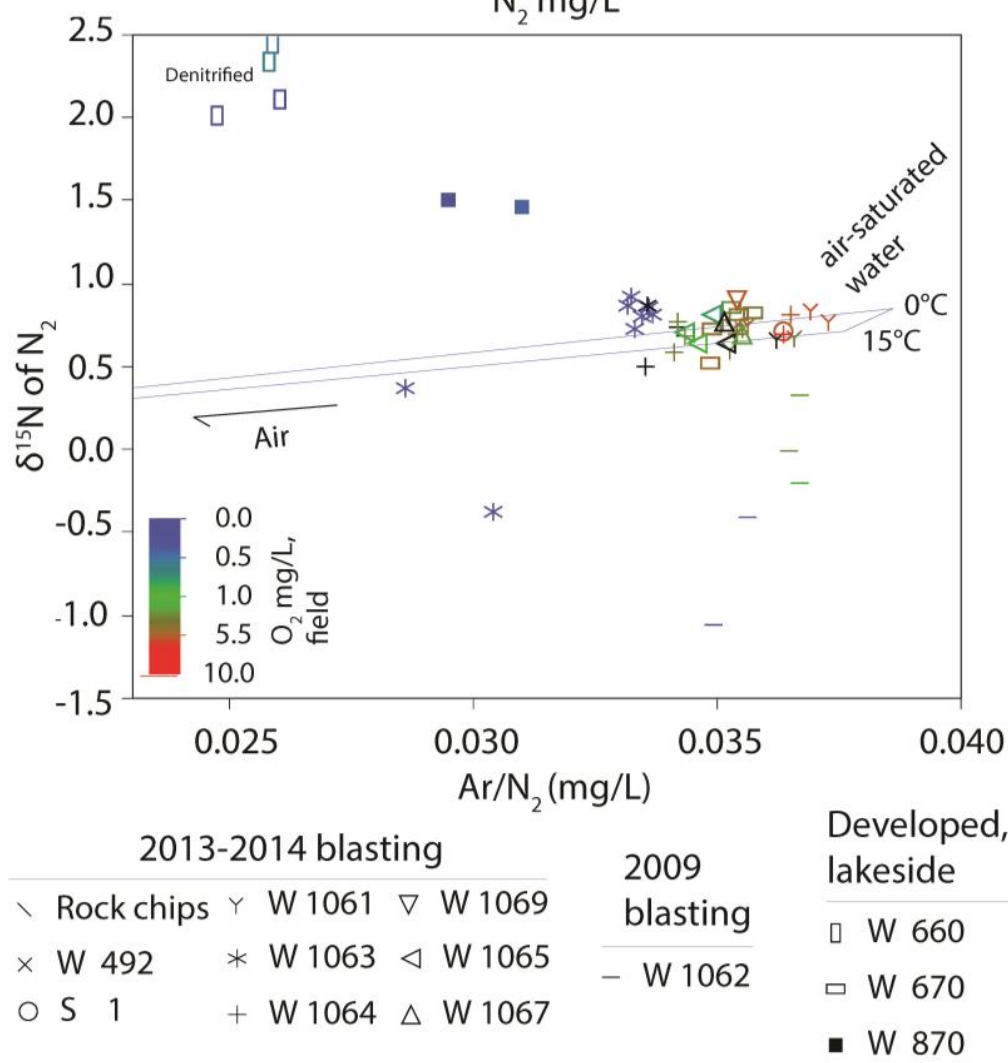

Figure S2. Chemical and isotopic data for dissolved gases, (A) $\mathrm{Ar}$ and $\mathrm{N}_{2}$ concentrations in comparison to those expected for air-saturated water at various equilibration temperatures and with varying amounts of excess air (cc-STP/L); (B) Relation between $\delta^{15} \mathrm{~N}_{\text {of }} \mathrm{N}_{2}$ and $\mathrm{Ar} / \mathrm{N}_{2}$ in comparison to those expected of air-saturated water and excess $\mathrm{N}_{2}$ from denitrification. Suboxic samples with relatively low $\mathrm{Ar} / \mathrm{N}_{2}$ ratios may contain excess $\mathrm{N}_{2} . \delta^{15} \mathrm{~N}$ values below those of than air-saturated water are more likely to indicate early stages of denitrification; $\delta^{15} \mathrm{~N}$ values above those of air-saturated water are more likely to indicate complete denitrification (see text). Black symbols represent samples with no field $\mathrm{O} 2$ data. 


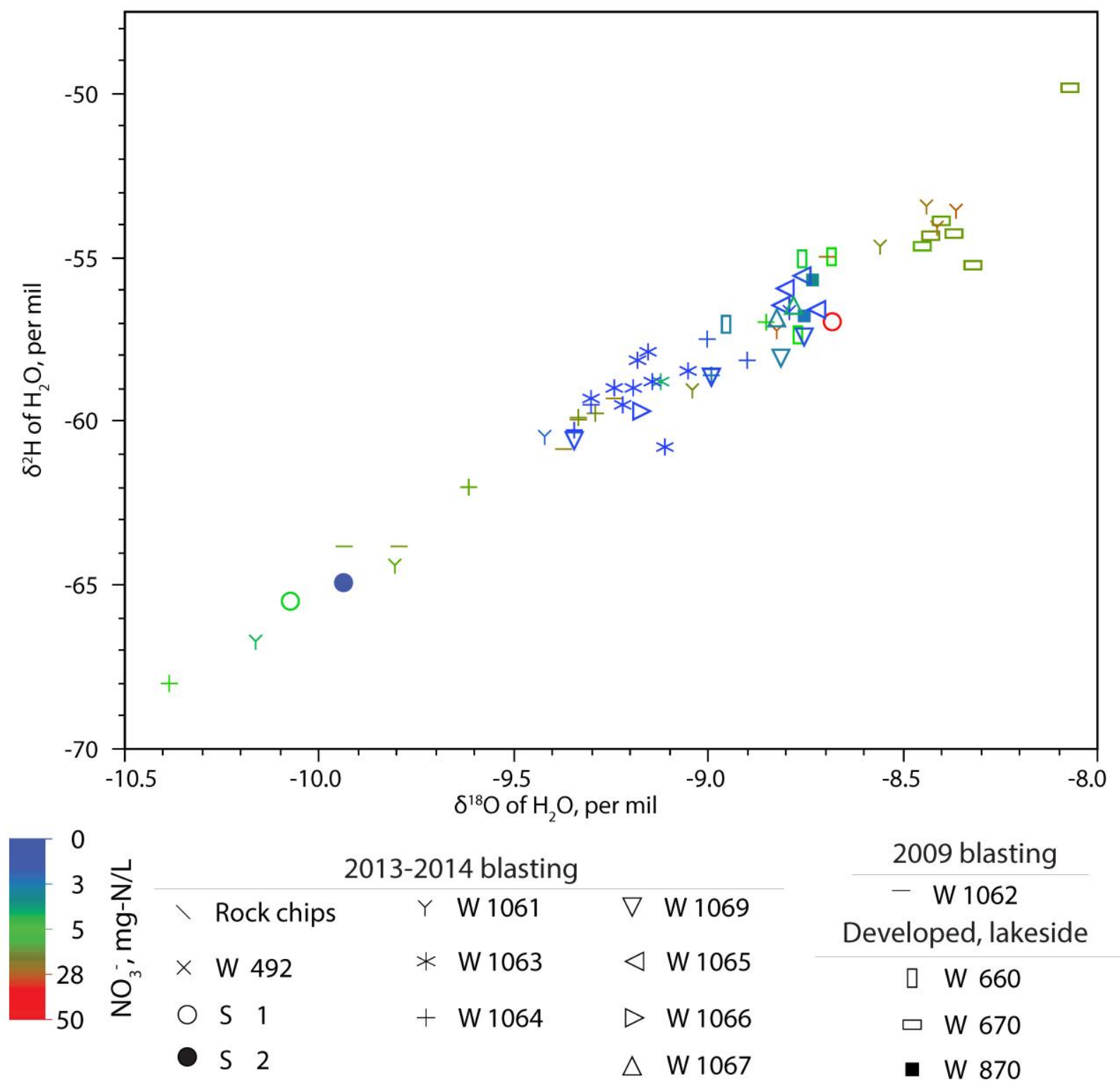

Figure S3. Isotopic data $\left(\delta^{2} \mathrm{H}\right.$ and $\left.\delta^{18} \mathrm{O}\right)$ for $\mathrm{H}_{2} \mathrm{O}$. 

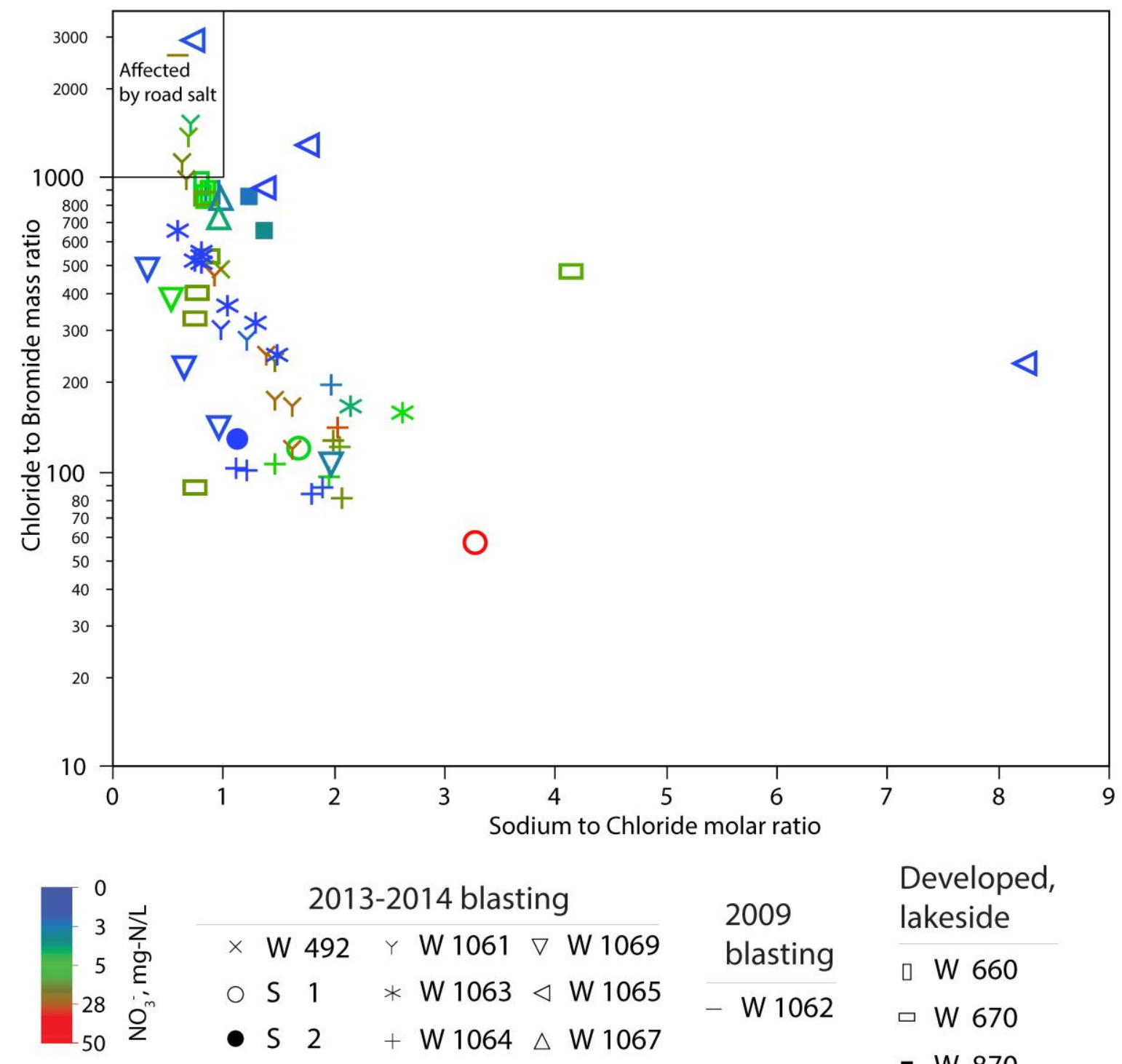

Developed, lakeside

2009

口 W 660

ㅁ W 670

- W 870

Figure $\mathrm{S} 4 . \mathrm{Cl} / \mathrm{Br}$ vs $\mathrm{Na} / \mathrm{Cl}$, molar ratios in wells and springs. 


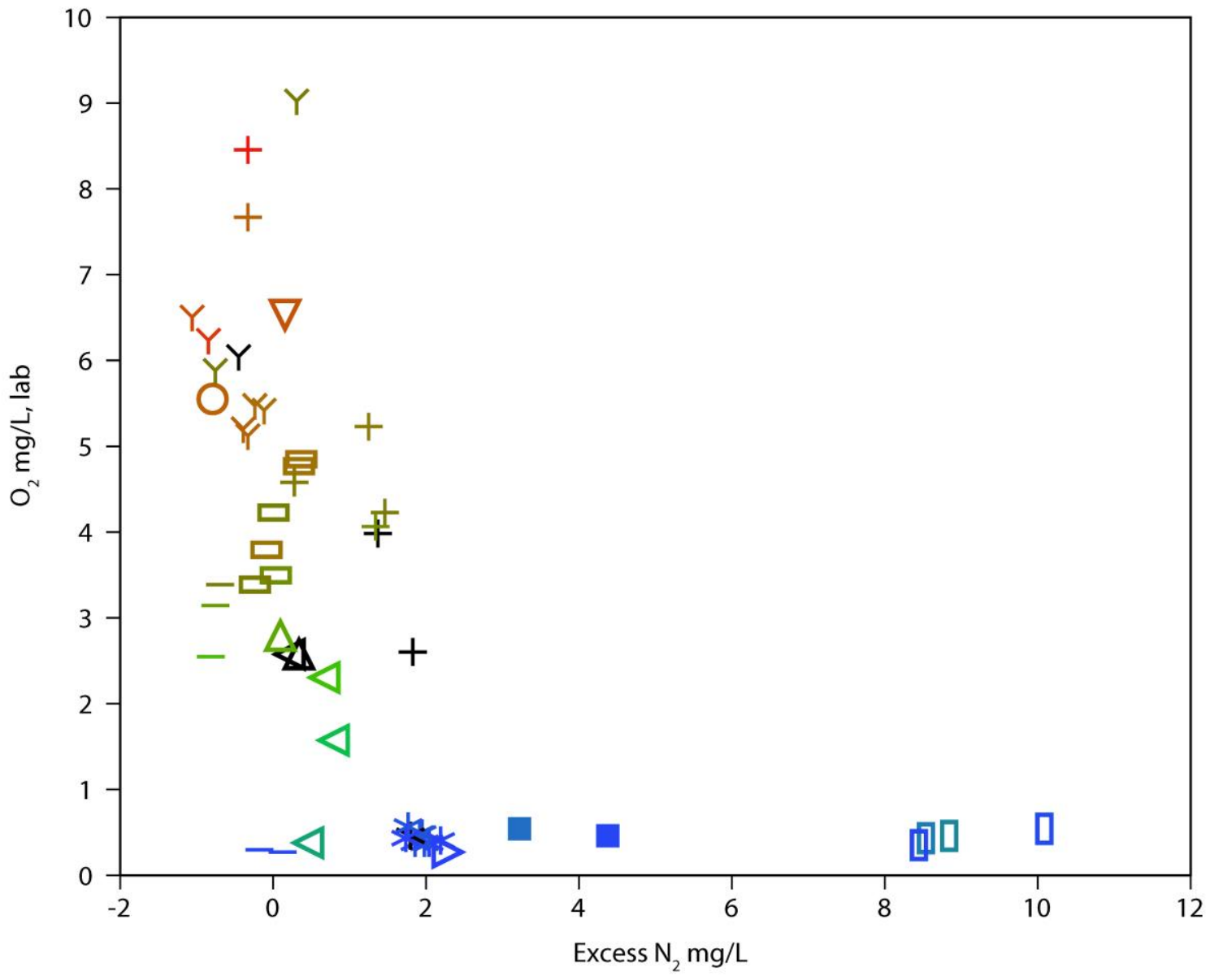

\begin{tabular}{|c|c|c|c|c|}
\hline 0.0 & \multicolumn{2}{|c|}{ 2013-2014 blasting } & 2009 & $\begin{array}{l}\text { Developed } \\
\text { lakeside }\end{array}$ \\
\hline 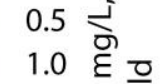 & $\times$ W 492 & Y W $1061 \nabla$ W 1069 & blasting & ㅁ W 660 \\
\hline $\begin{array}{l}5.5 \text { O } \\
10.0\end{array}$ & O $S 1$ & $\begin{array}{l}* W 1063 \triangleleft W 1065 \\
+W 1064 \triangle W 1067\end{array}$ & - W 1062 & $\begin{array}{l}\text { W } 670 \\
\text { W } 870\end{array}$ \\
\hline
\end{tabular}

Figure S5. $\mathrm{O}_{2}$ versus average (calculated using 1 and 4 cc excess air) excess $\mathrm{N}_{2}$ concentrations. Black symbols represent samples with no field $\mathrm{O}_{2}$ data. 


\section{References}

1. U.S. Geological Survey National field manual for the collection of water-quality data; U.S. Geological Survey Techniques of Water-Resources Investigations, chaps. A1-A9, variously dated; $p$ varies.

2. U.S. Geological Survey Reston Chlorofluorocarbon Laboratory. http://water.usgs.gov/lab/

3. U.S. Geological Survey Reston Stable Isotope Laboratory. http://isotopes.usgs.gov/

4. Jackson, W. A.; Böhlke, J. K.; Gu, B.; Hatzinger, P. B.; Sturchio, N. C., Isotopic composition and origin of indigenous natural perchlorate and co-occurring nitrate in the southwestern United States. Environmental Science \& Technology 2010, 44, (13), 48694876.

5. Coplen, T. B., Normalization of oxygen and hydrogen isotope data. Chemical Geology: Isotope Geoscience section 1988, 72, (4), 293-297.

6. Sigman, D. M.; Casciotti, K. L.; Andreani, M.; Barford, C.; Galanter, M.; Böhlke, J. K., A bacterial method for the nitrogen isotopic analysis of nitrate in seawater and freshwater. Analytical Chemistry 2001, 73, (17), 4145-4153.

7. Casciotti, K. L.; Sigman, D. M.; Hastings, M. G.; Böhlke, J. K.; Hilkert, A., Measurement of the oxygen isotopic composition of nitrate in seawater and freshwater using the denitrifier method. Analytical Chemistry 2002, 74, (19), 4905-4912.

8. Coplen, T. B.; Böhlke, J. K.; Casciotti, K. L., Using dual-bacterial denitrification to improve $\delta 15 \mathrm{~N}$ determinations of nitrates containing mass-independent 17O. Rapid Communications in Mass Spectrometry 2004, 18, (3), 245-250.

9. Böhlke, J. K., Sources, transport, and reaction of nitrate. In Residence times and nitrate transport in ground water discharging to streams in the Chesapeake Bay Watershed, ed.; Lindsey, B. D.; Phillips, S. W.; Donnelly, C. A.; Speiran, G. K.; Plummer, L. N.; Böhlke, J. K.; Focazio, M. J.; Burton, W. C.; Busenberg, E., Eds. U.S. Geological Survey, Water-Resources Investigations Report 2003-4035: 2003; pp 25-37

10. Holmes, R. M.; McClelland, J. W.; Sigman, D. M.; Fry, B.; Peterson, B. J., Measuring $15 \mathrm{~N}-\mathrm{NH} 4+$ in marine, estuarine and fresh waters: An adaptation of the ammonia diffusion method for samples with low ammonium concentrations. Marine Chemistry 1998, 60, (3-4), 235-243.

11. Böhlke, J. K., and Coplen, T. B., Interlaboratory comparison of reference materials for nitrogen-isotope-ratio measurements. In Reference and Intercomparison Materials for Stable Isotopes of Light Elements International Atomic Energy Agency: Vienna, 1995; pp 51-66.

12. Qi, H.; Coplen, T. B.; Geilmann, H.; Brand, W. A.; Böhlke, J. K., Two new organic reference materials for $\delta 13 \mathrm{C}$ and $\delta 15 \mathrm{~N}$ measurements and a new value for the $\delta 13 \mathrm{C}$ of NBS 22 oil. Rapid Communications in Mass Spectrometry 2003, 17, (22), 2483-2487.

13. Böhlke, J. K.; Denver, J. M., Combined use of groundwater dating, chemical, and isotopic analyses to resolve the history and fate of nitrate contamination in two agricultural watersheds, Atlantic Coastal Plain, Maryland. Water Resources Research 1995, 31, (9), 2319-2339.

14. Böhlke, J. K., Wanty, R., Tuttle, M., Delin, G., and Landon, M., Denitrification in the recharge area and discharge area of a transient agricultural nitrate plume in a glacial outwash sand aquifer, Minnesota. Water Resources Research 2002, 38, (7), 10-1-10-26. 
15. Green, C. T.; Puckett, L. J.; Böhlke, J. K.; Bekins, B. A.; Phillips, S. P.; Kauffman, L. J.; Denver, J. M.; Johnson, H. M., Limited occurrence of denitrification in four shallow aquifers in agricultural areas of the United States. Journal of Environmental Quality 2008, 37, (3), 994-1009.

16. Aeschbach-Hertig, W.; Peeters, F.; Beyerle, U.; and Kipfer, R., Interpretation of dissolved atmospheric gases in natural waters. Water Resources Research 1999, 35, 2779-2792.

17. Böhlke, J.K.; Verstraeten, I.M.; and Kraemer, T.F., Effects of surface-water irrigation on the sources, fluxes, and residence times of water, nitrate, and uranium in an alluvial aquifer. Applied Geochemistry 2007, 22, 152-174.

18. Beller, H. R., Biogeochemistry and natural attenuation of nitrate in groundwater at an explosives test facility. Applied Geochemistry 2004, 19, (9), 1483-1494.

19. Bordeleau, G., Determination of the origin of groundwater nitrate at an air weapons range using the dual isotope approach. Journal of Contaminant Hydrology 2008, 98, (3-4), 97.

20. Bordeleau, G.; Savard, M. M.; Martel, R.; Smirnoff, A.; Ampleman, G.; Thiboutot, S., Stable isotopes of nitrate reflect natural attenuation of propellant residues on military training ranges. Environmental Science \& Technology 2013, 47, (15), 8265-8272.

21. Bailey, B. L.; Smith, L. J. D.; Blowes, D. W.; Ptacek, C. J.; Smith, L.; Sego, D. C., The diavik waste rock project: Persistence of contaminants from blasting agents in waste rock effluent. Applied Geochemistry 2013, 36, (0), 256-270.

22. Pommen, L. W. The Effect on Water Quality of Explosives Use in Surface Mining; British Columbia Ministry of Environment: 1983; p 164. 